\title{
The Importance of Trust at The LeVel of Public International Law: A Contribution to Theoretical Considerations
}

\author{
HANNA DUSZKA-JAKIMKO*
}

\section{KEYWORDS}

trust, public international law, sources and principles of public international law, axiology

\begin{abstract}
The purpose of this article is to point to trust as a value serving the coexistence of international community cooperation, as well as the elimination of global threats in public international law. The article presents selected approaches and typology of trust adopted in social sciences (with particular emphasis on the sociology of law as an auxiliary science of jurisprudence), their reference to the understanding and meaning of trust in public international law, as well as consequences in the form of shaping the quality and content of legislative solutions and practice of acting in the international arena.

As a result of the conducted analyses, trust in international law can be considered in three ways: first, as trust in the binding rule established by the subjects of international law; second, as a value expressed by the axiology of international law and principles of institutional significance; third, as a requirement of effective practice that exemplifies the theoretical and axiological assumptions of law.
\end{abstract}

$\mathrm{PhD}$, Assistant Professor, Faculty of Law and Administration, University of Opole, E-mail: hannajakimko@uni.opole.pl; ORCID 0000-0002-6789-5043 


\section{INTRODUCTION}

In the literature, trust is discussed as one of the basic social values, necessary for the development of interpersonal relations and institutionalised social practice. ${ }^{1}$ As a subject of consideration in many scientific disciplines, including ethics, sociology, psychology, social anthropology but also the sociology of law, economics, or management theory, it is approached and defined differently. It is often associated with the issue of the predictability, stability, and security of social relations, minimising uncertainty related to the necessity of making decisions, and the issue of risks and threats present in contemporary social, economic, and political life. ${ }^{2}$ Works in these fields analyze the phenomenon of trust in various ways. Psychologically, they treat trust as a personality trait or an individual psychological predisposition of an individual that leads to trusting others. In the social dimension, they include trust as a relationship between individuals and groups and between individuals and institutions, as well as a moral commitment to actions beneficial to other individuals, as an attitude recognised in certain conditions as credible and ethical (axiological dimension). ${ }^{3}$ Trust is also treated as an element of capital social impact (including social ties) on the community's ability to cooperate in achieving its goals. A sociological approach analyses trust as a feature of a relationship, ie, direct or indirect exchange between individuals, associated with taking risks and directed towards the partner or as a relationship in an institutionalised social reality, which should have a

1 See Polish legal literature, eg, M Borucka-Arctowa, 'Zaufanie do prawa jako wartość społeczna i rola sprawiedliwości proceduralnej' in Teoria prawa. Filozofia prawa. Współczesne prawo i prawoznawstwo (Torun 1998) 15; P Kaczmarek, 'Zaufanie do zawodów prawniczych w społeczeństwie ryzyka' in H Izdebski, P Skuczyński (eds), Etyka prawnicza. Stanowiska $i$ perspektywy 2 (Warsaw, LexisNexis 2011) 11; P Skuczyński, 'Zaufanie (lojalność)' in H Izdebski, P Skuczyński (eds), Etyka zawodów prawniczych. Etyka prawnicza (Warsaw, CH Beck 2006) 99.

2 Different approaches to trust analyse F Fukuyama, F Fukuyama, Zaufanie. Kapitat społeczny a droga do dobrobytu (tr A and L Śliwa, Warsaw, PWN 1997); R Hardin, Zaufanie (tr A Gruba, Warsaw, Wydawnictwo Sic! 2009). A Giddens, Konsekwencje nowoczesności ( $\operatorname{tr}$ E Klekot, Kraków, Wydawnictwo Uniwersytetu Jagiellońskiego 2008); A Jaklik, M Łaguna, 'Zaufanie: sposoby ujmowania zjawiska i jego typologie'(2016) 59/3 Przegląd Psychologiczny 263-278; N Luhmann, Trust and Power (Chichester-Toronto 1979); N Luhmann, Systemy społeczne. Zarys ogólnej teorii (Kraków, Zakład Wydawniczy Nomos 2007); P Sztompka, Zaufanie. Fundament społeczeństwa (Kraków, Wydawnictwo Znak 2007), chapter III; id, 'Trust' in BS Turner (ed), The Cambridge Dictionary of Sociology 639.

3 In the Polish literature see A Jasińska-Kania, K Skarżyńska, 'Zaufanie do ludzi i instytucji w Polsce. Uwarunkowania psychologiczne i społeczno-polityczne' in M Zahorska, E Nasalska (eds), Wartości, polityka, społeczeństwo (Warszawa, Wydawnictwo Naukowe Scholar 2009) 60-78; K Skarżyńska, 'Zaufanie do ludzi. Efekt osobowości, doświadczeń socjalizacyjnych, sytuacji oraz systemu politycznego' in K Skarżyńska (ed), Między ludźmi... Oczekiwania, interesy, emocje (Warsaw, Wydawnictwo Naukowe Scholar 2012). 
'permanent identity and the invariability of the social and material environment in which we operate' 4 to create a sense of ontological security.

Therefore, trust is a socially acquired expectation, the subject of which is the regular and predictable behaviour of individuals on the basis of jointly recognised standards. ${ }^{5}$ The unpredictability of the contemporary world of late modernity and various threats (in the real world and cyberspace) lead to its definition as an anticipation of the future, as a 'bet on the future, uncertain actions of other individuals ${ }^{96}$ which aims to create in the awareness of both individual and general conviction about the credibility of actions aimed at the implementation of commitments undertaken. ${ }^{7}$

In jurisprudence, reflection on the category of trust is of interest to the theory and sociology of law, analysing it as a kind of systemic trust (and its abstract properties). Often, the literature on the subject is associated with trust in the binding rule as a model of conduct contained in the text of the normative act. The issue of trust is also present in the considerations of detailed legal sciences. Various forms of trusteeship, the guarantee of good faith in land and mortgage registers, the constitutional and legal principle of trust in the state and its law, the principle of protection of acquired rights, and the principles of family law are just a few examples in which the law is a substitute or alternative to trust, a necessary condition for the functioning of a particular legal institution or trust is a desirable object of protection. ${ }^{8}$

One of the goals of this article is to point out one more area of institutional and systemic trust - public international law, in which trust is of particular importance because of its function in the pursuit of security and the elimination of global threats.

\section{TRUST AS A SOCIOLOGICAL AND LEGAL CONCEPT}

The complexity of social life, the fragility of existing value systems, the intensification of risks, geopolitical problems, terrorism, nuclear weapons, environmental problems, human trafficking, and hunger in third world countries

4 Giddens (n 2) 92.

5 Jaklik, Laguna (n 2) 268.

6 Sztompka (n 2) 99.

7 Borucka-Arctowa (n 1) 17.

8 See P Machnikowski, Prawne instrumenty ochrony zaufania przy zawieraniu umowy (Wrocław, Wydawnictwo Uniwersytetu Wrocławskiego 2010); see also T Stawecki, 'Prawo i zaufanie. Refleksja czasu kryzysu' in J Oniszczuk (ed), Normalność i kryzys - jednolitość czy różnorodność. Refleksje filozoficzno-prawne $i$ ekonomiczno-społeczne $w$ ujęciu aksjologicznym (Warsaw, CeDeWu 2010). 
are just some of the global problems that are a source of uncertainty and volatility of social reality affecting both individuals and communities. ${ }^{9}$ They show how important the process of building trust and equipping the international community with a sense of security through trust in a trust mechanism can be to minimise the anxiety of modern societies.

From a legal perspective, these mechanisms are characterised by trust in a binding rule (norm) as a model of conduct, interpreted through the relationship between the law and the text of a normative act. ${ }^{10}$ This trust aims to make the future more predictable thanks to the binding legal rules indicating the way to behave, the obligation to take decisions, and indications of the consequences of behaviour that misappropriates the established rules or the consequences of not taking the necessary decisions. Therefore, trust in the public space is to be the basis for predictable actions of the entities of international law, defined in the political and procedural rules consistently with the binding norms. The specific systemic features of public international law, such as the specificity of the lawmaking process as a negotiating approach, the absence of an international legislator, the specificity of legal personality, voluntariness in assuming obligations, the absence of courts with enforced jurisdiction (no forced jurisdiction, ie, without the consent of the state, international jurisdiction) and centrally organised sanctions, ${ }^{11}$ lead to a reflection on whether and to what extent the concept of a binding rule ensures routine operation in international legal practice and how it affects a sense of existential security of the international community? Trust, considered as an abstract property of the system (connected with the sense of security), seems to be a particularly important mechanism of cooperation in the face of the growing number of new international conventions concluded by states and international organizations, which seems to be much stronger than formal and legal guarantees. It is precisely the specificity of international law that shows that trust is the foundation of actions (de facto agreements) between subjects of international law and, consequently, the basis of formal and legal regulations. Below, we will outline selected ways of presenting and typology of trust accepted in social sciences (with particular reference to the sociology of law as an auxiliary science of jurisprudence) and their references to understanding and meaning of trust in public international law, and further in the article we will

$9 \quad$ See Sztompka (n 2 'Trust') 639.

10 Kaczmarek (n 1) 19.

11 W Czapliński, A Wyrozumska, Prawo międzynarodowe publiczne (Warsaw, CH Beck 2014) chapter 3; as well as HLA Hart, Pojęcie prawa (translation and introduction by J Woleński, Warsaw, PWN 1998) 287; see also H Kelsen, Czysta teoria prawa (tr R Szubert, A Bosiacki (ed), Warsaw, LexisNexis 2014, chapter VII); R Kwiecień, Teoria i filozofia prawa międzynarodowego. Problemy wybrane (Warsaw, Difin 2011) 51-58. 
present their consequences in the form of shaping the quality and content of legislative solutions, as well as the practice of acting on the international arena.

Trust, generally speaking, arises from the multiple exchange of services between individuals (subjects), ie, in a relationship. This is one of the key ways of understanding the phenomenon of trust. Trust, understood as a relationship formed between entities, is based on the following criteria: reciprocity (exchange of favours, benefits, moral obligations), diagonality (relations between two entities), permanence (long duration of the relationship), and rationality (the aim of the exchange is to maximise benefits and calculate profits and costs). ${ }^{12}$ This relationship consists in providing a certain benefit (good) to one entity "which is linked to the obligation to reciprocate and the expectation of reparation on the other hand". ${ }^{13}$ Therefore, the basis of the relationship can be both (1) a moral obligation to comply with the commitment made and (2) the pursuit of tangible and intangible benefits. ${ }^{14}$ Trust is a legitimate expectation of the conduct of some entities towards others: individuals, social groups, organizations, in accordance with the binding rules of conduct. It is a trust that can appear in various contexts: in those related to activities of an instrumental and rational character relations (eg, commercial transactions, services, contracts) as well as those with a cultural dimension expressed in values shared by entities, in their perception of them as external and having normative values determining the rules of conduct and cognitive functions (values determining the content and meaning of actions undertaken). ${ }^{15}$ Trust can also be the result of analysing attributes and estimating the partner's credibility on the basis of criteria such as character traits, behaviour and attitudes. ${ }^{16}$ Credibility is an essential factor in relationship-based trust that minimises individual uncertainty by introducing predictability and compliance with expectations. ${ }^{17}$ Uncertainty and risk are inherent elements in the phenomenon of trust, because they enable a specific action to be taken and allow for dealing with a dynamic and unpredictable reality. Therefore, trust is considered, with regard to the above observations, as a 'rational strategy for dealing with risky exchange situations'. ${ }^{18}$ And durability and predictability are exemplified by the applicable rule (standard). Their aim - in general terms - is to create a permanent institutional framework for the future behaviour of entities, and thus the credibility

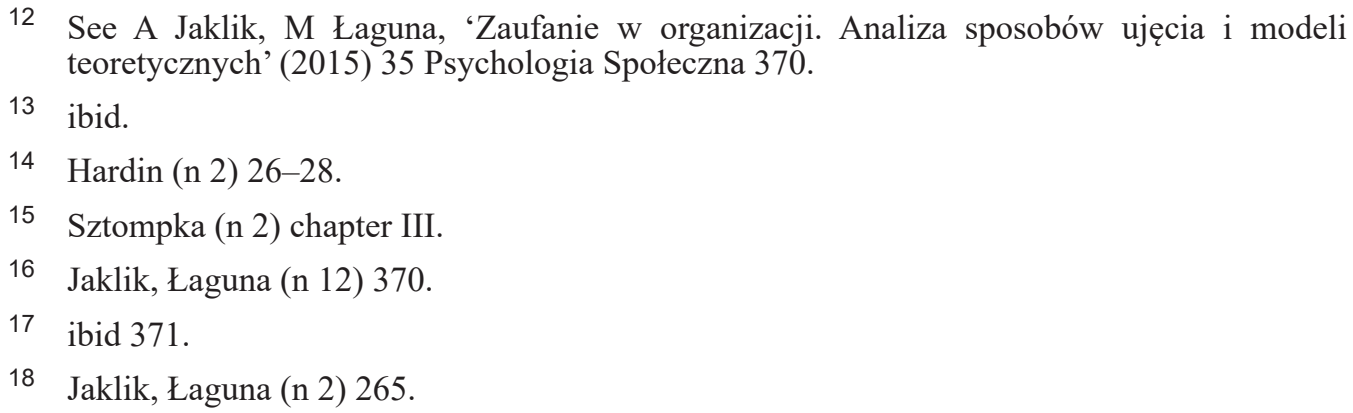


of these behaviours. P. Sztompka stresses that such an approach in fact moves closer to the concept of legal legitimacy assuming institutional and procedural trust in the actions of entities, including authorities. ${ }^{19}$ Trust in the law determines the advancement of specific legal arguments so that - referring to the abovementioned sociological notions of trust - 'a bet [is] taken on the uncertain future actions of other people'. P. Sztompka could refer to evaluation criteria, both instrumental and essential, related to the values of the system such as the rule of law, non-retroactivity, legalism, impartiality, consistency, as well as to their ideas - justice, purpose and security. ${ }^{20}$ In so doing, it creates an institutional structure implying adherence to established rules.

The science of sociology also points, although not without a doubt, to the mutual relations of trust and social capital. Social capital means trust, norms, and social bonds formed on the basis of socially accepted and respected norms, longterm mutual relations, involvement of entities in order to realise common interests, both individual, group, and general social. Trust is seen here as an ability to 'bring people together within groups and organisations to pursue common interests' ${ }^{21}$ According to J. Coleman, social capital is an ethically and morally neutral resource, and as such it allows social 'organisations' in order to realise common interests and intentions. In this way, it defines a specific social expectation in the form of taking responsibility for the realisation of common goals.

According to F. Fukuyama, social capital is normatively conditioned and depends on the level of trust within society and compliance with the norms of reciprocity. It is a 'set of informal values and ethical norms, common to members of a given group and enabling them to cooperate effectively'. ${ }^{22}$ Social capital refers to features such as loyalty, honesty, and reliability; building deepened relationships between individuals ${ }^{23}$ refers to 'interpersonal capital' enabling the achievement of social goals, ${ }^{24}$ to 'networks of relations between citizens, based

19 Sztompka (n 2) 109-110.

20 S Wronkowska, 'Kryteria oceny prawa' in E Kustra (ed), Przemiany polskiego prawa (19891999) (Toruń, Wydawnictwo Uniwersytetu Mikołaja Kopernika 2001) 33-46; J Zajadło, 'Bezpieczeństwo - celowość - sprawiedliwość: antynomie idei prawa' in J Jabłońska-Bonca, J Guść (eds), Problemy bezpieczeństwa prawnego perspektywy teorii i filozofii prawa (2002) IX Gdańskie Studia Prawnicze 233-248.

21 J Coleman, 'Social Capital in the Creation of Human Capital' (1988) 94 American Journal of Sociology $95-120$.

22 F Fukuyama, Kapitat spoleczny, in LE Harrison, SP Huntington (eds), Kultura ma znaczenie. Jak wartości wpływają na rozwój społeczeństw (tr S Dymczyk, Poznań, Wydawnictwo Zysk 2003) 169.

23 Coleman (n 21) 96.

Hardin (n 2) 87. 
on cooperation and facilitating the solution of common problems ${ }^{25}$ to "the ability of individuals to act for the common good within social groups and institutions' ${ }^{26}$ The existence of social capital makes it possible for a given community to cooperate in solving emerging conflicts through various informal mechanisms without resorting to legal sanctions. ${ }^{27}$

According to F. Fukuyama, trust is 'a mechanism based on the assumption that other members of a given community are characterised by fair and cooperative behaviour based on commonly professed norms'. From this perspective, trust refers to the moral aspect of common values and is analysed from a social perspective by means of which is a culturally determined value through which society can 'cope' with an uncertain and uncontrollable future.

In terms of R. D. Putnam's social capital is a moral resource (value-added approach) that affects the ethical standards of a given community, respect for the principles of equality, honesty, norms of reciprocity (observance and fulfilment of obligations) and trust. According to the author, social capital is 'networks, norms and trust - which enable participants to work together more effectively in pursuit of common goals'. ${ }^{28}$ When the social partners' actions are based on accepted standards, they are perceived as trustworthy and contribute to social development and cooperation. Trust as a moral obligation provides the basis for credible commitment and honesty in the actions of others and is created when 'a community shares a set of moral values, which allows the expectation of regular and honest conduct'. ${ }^{29}$

The stressing of the importance of trust in the context of the mechanism of cooperation of social entities in the fulfilment of obligations undertaken and common goals indicates the impact of trust on various areas of social life. ${ }^{30}$ The sociology of law applies the findings of the social sciences having as its subject the phenomenon of trust emphasising its understanding as relations between subjects in the sphere of private and public law based on trust in the rule and expression of cooperation (influencing the sense of security) and as a social value conducive to the emergence of a culture of trust. The culture of trust, as noted by P. Sztompka, is a property of the whole society when the rules requiring trust are divided in the community and perceived as imposed on (external) individuals.

25 J Brehm, W Rahn, 'Individual - Level Evidence for the Causes and Consequences of Social Capital' (1997) 41 American Journal of Political Science 999, quoted after R Hardin (n 2) 85.

Fukuyama (n 2) 14.

ibid 38.

R Putnam, 'Turning In, Turning Out: The Strange Disappearance of Social Capital in America’ (1995) 12 Political Science and Politics 664-683, cited in P Sztompka (n 2) 41.

Fukuyama (n 2) 40.

Borucka-Arctowa (n 1) 16-18. 
Only then do they exert a 'strong pressure to put pressure on or deny real acts of trust'. ${ }^{31}$

It should be stressed that the most complex understanding of trust and, at the same time, trust is of particular importance in a cooperative situation. This happens when the actors 'acting together, work together towards a goal that cannot be achieved on their own' ${ }^{32}$ As the author of these words, P. Sztompka, emphasises, cooperation is expressed in the actions of all stakeholder partners aimed at achieving the intended objective and thus at achieving success. Trust is a prerequisite for cooperation, a capacity (skill) for social development within different organisations and structures. It is a general, abstract trust, which means that trust is placed not in individuals (in their interpersonal relations) but in the abstract properties of these systems. Therefore, it is built both on the basis of a clear definition of the objectives to be achieved by the partners and on the basis of a clear definition of the rules of procedure for actions taken (such as rationality, certainty, consistency, and thus the requirements of procedural justice), as well as the rules for the allocation of powers and responsibilities (distributive justice).

\section{INTERNATIONAL LAW AND ASPECTS OF TRUST}

International law, because of its normative scope and systemic differences in relation to national law, is understood in different ways in the field of jurisprudence. Widely known in the literature are both the positions questioning the jurisdictional nature of international law and its legitimacy as a legal system on account of the assumptions of legal positivism ${ }^{33}$ that dominated in the 19th and 20th centuries and those that treat international law as a model of law and stress such constitutive features as equality, reciprocity, voluntariness, proportionality, negotiation character, and normative character of sources. ${ }^{34}$ Relations between subjects of international law are not regulated by any supranational center of political disposal (international authority) and therefore there is no centralised supranational coercive apparatus. ${ }^{35}$ The foundation for legitimate actions in the international space are, first of all, legally binding bilateral and multilateral agreements concluded by sovereign states and other entities of international law according to

31 Sztompka (n 2) 144.

32 ibid 138.

33 As represented by T Hobbes, GF Puchta, B Spinoza and J Bentham; see R Kwiecień (n 11) chapter I.

34 W Czapliński, A Wyrozumska (n 11) chapter 2.

35 See J Stelmach, R Sarkowicz, Filozofia prawa XIX i XX wieku (Kraków, Wydawnictwo Uniwersytetu Jagiellońskiego 1999). 
the principles of voluntariness, equality, and reciprocity; second, international customs; and last but not least, other forms of soft law. ${ }^{36}$ The intensity and complexity of international relations require an increasing number of new treaty regulations and strives to ensure the international community's sense of security by means of their jurisprudence. ${ }^{37}$ This situation gives rise to various implications for the definition of the role of trust in international law.

Trust in international law should be read first of all in the context of trust in actions taken on the basis of the binding rule that is a model of conduct determining the rights and obligations of entities governed by international law in the content of normative acts. The legitimacy of binding regulations legitimises decisions taken on their basis and creates an institutional framework for action, including rules that verify and control these behaviours. Trust becomes then the source of functioning and the basis for cooperation of the international community, which creates an axiologically diverse cultural circle and has a 'non-local' character. Trust, understood as trust, becomes a legitimate expectation of specific actions of the subjects of law and consequently implies the use of specific legal arguments of an institutional and procedural nature, such as legal certainty, its stability, semantic cohesion, equality, and reciprocity. ${ }^{38}$ Thus, trust at the level of international legal relations assumes, first of all, a horizontal character: first, because of the nature of legal regulations expressed in a negotiating type of lawmaking; second, because of the equivalence of entities of international law; third, because of procedural rules concerning the legality, rationality, objectivity, rule of law, and transparency of the entities' actions and obligations arising from them; and fourth, by indicating the rules of mutual distribution of powers and obligations arising from treaty obligations. This makes trust one of the guarantees of compliance with the applicable rules of conduct that form the framework for the activities of legal entities.

Second, trust at the level of international law should also be read in the context of complex cooperation ${ }^{39}$ in various areas of international activity in order to minimise different types of risks and threats appearing in the new reality of international relations. This cooperation expresses the stabilising and safeguarding function of international law against disintegration and inefficiency, as well as compliance with the obligations that shape this cooperation. Third, cooperation between entities governed by international law must be regarded as

36 See Art. 38.1 of the ICJ Statute (Journal of Laws of the Republic of Poland 1947, no 23, item 90); L Łukaszuk, 'Współczesne prawo międzynarodowe i jego relacje z prawem krajowym (wybrane zagadnienia)' in J Menkes (ed), Prawo międzynarodowe - problemy $i$ wyzwania. Księga pamiatkowa Profesor Renaty Sonnenfeld-Tomporek (Warsaw 2006) 392-394.

37 A Wyrozumska, Umowy międzynarodowe. Teoria i praktyka (Warsaw, Prawo i Praktyka Gospodarcza 2006).

38 Kwiecień (n 11 ) chapter 6.

39

Sztompka (n 2) 138-141. 
a complex expression of trust originating in several categories: (1) a normative obligation to implement treaty provisions resulting from the applicable treaty regulations and from the axiology of international law, referring to principles such as good faith, pacta sunt servanda, estoppel, equity, ${ }^{40}$ and cultural values such as loyalty, sense of responsibility, and respect for mutual obligations; (2) claims to enforce treaty provisions which constitute mutual benefits of a tangible and intangible nature (purposeful rationality, based on cost calculation, as well as a strategy in pursuit of a specific objective), ie, claims to act rationally and effectively and to undertake rational, effective action and to take action in order to achieve a specific objective); (3) claims to enforce treaty provisions that constitute mutual benefits of a tangible and intangible nature (purposeful rationality, based on cost calculation, as a strategy in pursuit of a specific objective), ie, claims to act rationally and effectively and to take action in accordance with a specific objective.

In reference to the first aspect, trust is expressed in a binding rule treating both the theoretical requirements of justifying binding norms and determining the behaviour of the subjects of that law. In international law it consists mainly of the theory of the so-called consent of states (Lotus doctrine), ${ }^{41}$ considered - despite many reservations and criticisms of the doctrine - as a form of legitimising international law. It refers both to the legitimisation of states' mutual treaty obligations and to customary law. According to some authors, in the absence of a supra-state factor in international law, the basis for the binding force of norms of international law is a declaration of will of the individual subjects of this law, issued on the basis of the rules of the legal order of the state. This constitutes the so-called thetic justification of the binding force of the norm, associated with the legislative competence of the legitimate legislator, the specific procedure of incorporation and promulgation of the legal text (in this case, international agreements).

Many objections to the theory of consent of states (concerning, inter alia, the possibility of ignoring the discrepancies between the objectives of states and the objectives of the international community, the possibility of sanctioning the gaps, the impossibility of consolidating the principle of rule of law in international relations, relativisation showing the possibility of the arbitrariness of the content of norms ${ }^{42}$ ) point to its horizontal dimension of action focusing primarily on the

40 See Art. 26 of the Warsaw Convention, done in Vienna on 23 May 1969 (Journal of Laws of the Republic of Poland 1990, no 74, item 439); see also R Kwiecień (n 11) chapter 6; A Kozłowski, Estoppel jako ogólna zasada prawa międzynarodowego (Wrocław, Wydawnictwo Uniwersytetu Wrocławskiego 2009); W Czapliński, A Wyrozumska (n 11) 131-144.

41 The theory of the so-called consent of states touching upon the problem of legitimacy of international law finds its expression in the jurisprudence of the so-called Lotus doctrine formulated by the Permanent Court of International Justice; for more detail see R Kwiecień (n 11) 115-118.

ibid 119. 
respect of interests and rights and obligations between states and omitting the dimension of 'international justice' focusing on the legal and international protection of human rights. ${ }^{43}$ In this approach the supra-individualistic vision of law prevails over the individualistic conception, which indicates the primacy of the interests of the state over the protection of the rights and representation of the interests of its citizens. ${ }^{44}$ Hence, another interpretation of trust in law arises, understood as the ability to cooperate in modern international law, first, in order to protect human rights, which indicates the importance of the individualistic perspective of the influence of modern international law having its source in the moral obligation, ${ }^{45}$ second, in order to protect the freedom of states ${ }^{46}$ At this level, international law appears as a normative order existing for the protection of values perceived by the international community as a common good. The specific systemic features of public international law, ${ }^{47}$ such as the specificity of the lawmaking process expressed in the negotiation approach, the absence of an international legislator (the norms of international law are binding only on those entities that participated in their creation, and only such norms can be invoked against that entity), the specificity of the subjects of this law, the sovereign equality of states, the voluntariness and reciprocity in accepting obligations, the lack of courts equipped with coercive jurisdiction (the lack of coercive power, ie, power without the consent of the state, without international jurisdiction), and the lack of centrally organised sanctions result in specific objectives and functions of this law.

Also, the concept of the formal sources of law expressed in Article 38 (1) of the Statute of the International Court of Justice of 26.06.1945 $5^{48}$ and the methods of interpretation of treaties, the question of norms ius cogens (cf. Article 53 of the Vienna Convention on the Law of Treaties of 23.05.196949), according to which international agreements and custom may not violate the mandatory norms and

43 ibid 119-121.

44 Therefore, the so-called theory of consent of states should be read as an instrument for lawmaking, not as the ultimate basis for its legitimacy; for more detail, see R Kwiecień (n 11) 139.

Cf T Kozłowski, Filozoficzność prawa jako prawo zdeetatyzowane wedlug Andrzeja Stelmachowskiego, in Prawo w dobie globalizacji (Warsaw 2010) 32.

46 This is a reference to the issue of legitimacy of international law in the view of I. Kant. For more detail, see R Kwiecień (n 11) 142-143; for the same: 'Prawo w perspektywie filozofii Kanta' in Między wartościa wspólnoty a wspólnota wartości. Studia i szkice z filozofii prawa idealizmu niemieckiego (Lublin, Wydawnictwo Verba 2007) $31 \mathrm{ff}$.

47 CfW Czapliński, A Wyrozumska (n 11) chapter 3; also, HLA Hart (n 11) 287. The positivistic reflection on the juridical nature of international law is analysed in greater detail by $\mathrm{R}$ Kwiecień (n 11) 51-58. The positivist reflection on the juridical character of international law is analysed in more detail: see H Kelsen (n 11) chapter VII.

Journal of Laws of the Republic of Poland 1947, no 23, item 90.

Journal of Laws of the Republic of Poland 1990, no 74, item 439. 
ius cogens causes invalidity of the contradictory contract, custom, or unilateral act and limits the freedom of the subjects of international law to create law 'allowing to depart from the prohibition of certain conduct in international law'. ${ }^{50}$ The invalidity of a treaty contrary to the norm of ius cogens and the lack of consent of the international community to violations of norms of this nature are the two most significant consequences of legal and moral significance (invalidity and lack of universal international acceptance). The recognition of a norm as peremptory is related to the determination of its special importance for international law and depends on the interpretation of this norm and the acceptance of its imperative character by the international community. However, in a situation where the parties concluding a treaty consider the treaty valid and not in violation of the norm of ius cogens, this only results in the possibility of finding such a violation and declaring the treaty invalid only against third states.

The declaration of will of the parties in an international agreement (in accordance with the rules of system and procedure of a given legal order) has a constitutive and lawmaking significance and constitutes a point of reference for the examination of the essence and nature of the obligations arising ${ }^{51}$ (it seems, however, that such an approach, recognised by international actors to the interpretation of the norms of international law causes the risk of their instrumentalisation and relativisation, as adequate or inadequate to the needs of political nature and the possibility of using the gaps, which is associated with the discretion of power). Although nowadays treaties are the most common form of creating norms of international law, and among the basic sources of international law, it is difficult not to notice that the diversity of international relations and interests requires an increase in the importance of other informal sources, such as lawmaking treaties and soft law, ${ }^{52}$ in which international legal obligations can be derived from the form, content, or context of the agreement..$^{53}$ Also, the values already mentioned, forming the core of the understanding of international law, such as equality and independence of subjects of international law, reciprocity in observing rights and obligations, good faith, pacta sunt servanda, estoppel, and equity, are necessary components of trust. Axiological justification thus requires

50 Czapliński, Wyrozumska (n 11) 39-46.

51 Czapliński, Wyrozumska (n 11) 45.

52 For a broader discussion of the issues of creation, validity, and effectiveness of international agreements (treaty law) and new forms of lawmaking by international organizations, see, among others, A Aust, Modern Treaty Law and Practice (Cambridge University Press 2007) 16-23; J Crawford, Public International Law (Oxford University Press 2012) 367-377; A. Wyrozumska (n 37); W Czapliński, A Wyrozumska (n 11) 56-63; A Wyrozumska, 'Obiektywna czy subiektywna koncepcja umowy międzynarodowej?' in J Menkes (ed), Prawo międzynarodowe - problemy $i$ wyzwania. Księga pamiatkowa Professor Renata Sonnenfeld - Tomporek (Warsaw 2006) 540-555.

See Wyrozumska (n 52) 553-555. 
the identification of a set of judgements and the values they designate and an indication of the extent to which they are to be legally binding. Basing trust in international law on an order of values is one of the conditions for its existence.

The last of the distinguished meanings of trust is the criterion of effectiveness. The issue of effectiveness, as $\mathrm{H}$. Kelsen notes, is a condition of validity insofar as it is assumed (taken into account) in the very process of norm making, as happens in international law. ${ }^{54}$ The effectiveness of a norm is an ontic fact (application and observance), a connection between the norm's duty and the existence of natural reality, although it cannot be identified with its validity. The importance and complexity of this issue is particularly evident from the perspective of positivist legal theory. This complexity results from the methodological assumptions, among which the objectivist-idealist theories emphasise the complete independence of the binding force of a norm from its effectiveness, while others, such as the realist-relativist theories assume that the binding force of a law is identical to its effectiveness, since its establishment itself is already an ontic act. ${ }^{55}$ H. Kelsen, on the other hand, proposes the assumption that the effectiveness of the legal order as well as of a single norm is a condition of validity in the sense that the legal order as a whole as well as individual norms are not perceived as valid when they cease to be effective. The permanent lack of application as well as non-observance of the norm (as in the case of desuetudo) in H. Kelsen's opinion results in the loss of its validity, because the function of desuetudo as a negative custom (understood as a law-giving state of affairs showing the lack of its application and observance) results in the abrogation of its validity. ${ }^{56}$

The fulfillment of conditions related to the mode of concluding an agreement, its entry into effect, validity, the consent of the subject to be bound by the agreement (conditions arising from the content of the Vienna Convention on the Law of Treaties of 23.05.1969 ${ }^{57}$ ) and the application of an international agreement, ie, the execution of the agreement in good faith in accordance with the principle of pacta sunt servanda (Article 26 of the Convention), and the primacy of the provisions of the agreement over 'any incompatible rules of customary law, except for the rules of iuris cogentis ${ }^{58}$ are the elements expressing the essential requirements for the effectiveness of an international agreement. At the same time, a party to an agreement cannot, due to the lack of its implementation in domestic law, plead its non-application. Such a situation raises issues of international liability for failure to implement the provisions of the treaty.

\footnotetext{
54 Kelsen (n 11) 69.

55 ibid 319.

56 Kelsen, General Theory of Law and State (tr A Wedberg, Clark, New Jersey 2009) 119-120.

57 Journal of Laws of the Republic of Poland 1990, no 74, item 439.

58 Czapliński, Wyrozumska (n 11) 609.
} 
Doctrine has resulted in and continues to result in multifaceted analyses of the practical components of the effectiveness of an international agreement - its observance, application, and interpretation. The present considerations aim only to highlight the aspects related to the construction of community capital - trust in international law - and connected with its axiological and systemic requirements.

\section{Conclusions}

F. Fukuyama's understanding of trust, which we mention above, is reflected in the trust manifested in the cooperation and integration of the international community, both in the perspective of factual as well as formal and legal agreements.

The mechanism of trust expressed in the stabilisation function, in striving for the sustainability of the social and material environment of activities ${ }^{59}$ is aimed at reducing uncertainty and risk within the framework of international cooperation and external relations.

Trust in the law as an expression of abstract properties of the legal system - valid rules, principles, and values guaranteed and protected by the law -affects the credibility of the law and its certainty, as well as the binding of the category of trust to the category of responsibility of the various entities for the implementation of obligations undertaken.

Trust at the international level is thus one of the requirements through which a community of peoples can be built through an order of values (not the coercive order characteristic of state law) and practice that honours the protected values.

In international law, trust can be considered in three ways: (1) first, as trust in a binding rule that embodies the theoretical aspects of the justification of the validity of law; (2) second, as a value expressed by the axiology of international law and principles of institutional significance; (3) third, as a requirement of effective practice that exemplifies the theoretical and axiological assumptions of law.

\section{References}

Aust A, Modern Treaty Law and Practice (Cambridge University Press 2007)

Borucka-Arctowa M, 'Zaufanie do prawa jako wartość społeczna i rola sprawiedliwości proceduralnej' in Teoria prawa. Filozofia prawa. Współczesne prawo i prawoznawstwo (Toruń 1998) 
Brehm J, Rahn W, 'Individual - Level Evidence for the Causes and Consequences of Social Capital' (1997) 41 American Journal of Political Science

Coleman J, 'Social Capital in the Creation of Human Capital' (1988) 94 American Journal of Sociology

Crawford J, Public International Law (Oxford University Press 2012)

Czapliński W, Wyrozumska A, Prawo międzynarodowe publiczne (Warsaw, CH Beck 2014)

Fukuyama F, Zaufanie. Kapitat społeczny a droga do dobrobytu (tr A and L Śliwa, Warsaw, PWN 1997)

Fukuyama F, 'Kapitał społeczny' in LE Harrison, SP Huntington (eds), Kultura ma znaczenie. Jak wartości wpływają na rozwój społeczeństw (tr S Dymczyk, Poznań, Wydawnictwo Zysk 2003)

Giddens A, Konsekwencje nowoczesności (tr E Klekot E, Kraków, Wydawnictwo Uniwersytetu Jagiellońskiego 2008)

Hardin R, Zaufanie (tr A Gruba, Warsaw, Wydawnictwo Sic! 2009)

Hart H, Pojęcie prawa (translation and introduction by Woleński J, Warsaw, PWN 1998)

Jaklik A, Łaguna M, 'Zaufanie w organizacji. Analiza sposobów ujęcia i modeli teoretycznych' (2015) 35 Psychologia Społeczna

Jaklik A, Łaguna M, 'Zaufanie: sposoby ujmowania zjawiska i jego typologie' (2016) 59/3 Przegląd Psychologiczny

Jasińska-Kania A, Skarżyńska K, 'Zaufanie do ludzi i instytucji w Polsce. Uwarunkowania psychologiczne i społeczno-polityczne’ in M Zahorska, E Nasalska (eds) Wartości, polityka, społeczeństwo (Warszawa, Wydawnictwo Naukowe Scholar 2009)

Kaczmarek P, 'Zaufanie do zawodów prawniczych w społeczeństwie ryzyka' in H Izdebski, P Skuczyński (eds), Etyka prawnicza. Stanowiska i perspektywy 2 (Warsaw, LexisNexis 2011)

Kelsen K, General Theory of Law and State (tr A Wedberg, Clark, New Jersey 2009)

Kelsen K, Czysta teoria prawa (tr R Szubert R, A Bosiacki (ed), Warsaw, LexisNexis 2014)

Kozłowski A, Estoppel jako ogólna zasada prawa międzynarodowego (Wrocław, Wydawnictwo Uniwersytetu Wrocławskiego 2009)

Kozłowski T, 'Filozoficzność prawa jako prawo zdeetatyzowane według Andrzeja Stelmachowskiego' in Prawo $w$ dobie globalizacji (Warsaw 2010)

Kwiecień R, Teoria i filozofia prawa międzynarodowego. Problemy wybrane (Warsaw, Difin 2011)

Kwiecień R, 'Prawo w perspektywie filozofii Kanta' in Między wartościq wspólnoty a wspólnota wartości. Studia $i$ szkice z filozofii prawa idealizmu niemieckiego (Lublin, Wydawnictwo Verba 2007)

Luhmann N, Trust and Power (Chichester-Toronto 1979)

Luhmann N, Systemy społeczne. Zarys ogólnej teorii (Kraków, Zakład Wydawniczy Nomos 2007)

Łukaszuk L, 'Współczesne prawo międzynarodowe i jego relacje z prawem krajowym (wybrane zagadnienia)' in J Menkes (ed), Prawo międzynarodowe-problemy i wyzwania. Ksiega pamiatkowa Profesor Renaty Sonnenfeld-Tomporek (Warsaw 2006)

Machnikowski P, Prawne instrumenty ochrony zaufania przy zawieraniu umowy (Wrocław, Wydawnictwo Uniwersytetu Wrocławskiego 2010) 
Putnam R, 'Turning In, Turning Out: The Strange Disappearance of Social Capital in America' (1995) 12 Political Science and Politics

Skarżyńska K, 'Zaufanie do ludzi. Efekt osobowości, doświadczeń socjalizacyjnych, sytuacji oraz systemu politycznego' in K Skarżyńska (ed), Między ludźmi... Oczekiwania, interesy, emocje (Warsaw, Wydawnictwo Naukowe Scholar 2012)

Skuczyński P, 'Zaufanie (lojalność)' in H Izdebski, P Skuczyński (eds), Etyka zawodów prawniczych. Etyka prawnicza (Warsaw, CH Beck 2006)

Stawecki T, 'Prawo i zaufanie. Refleksja czasu kryzysu' in J Oniszczuk (ed), Normalność $i$ kryzys - jednolitość czy różnorodność. Refleksje filozoficzno-prawne i ekonomiczno-społeczne w ujęciu aksjologicznym (Warsaw, CeDeWu 2010)

Stelmach J, Sarkowicz R, Filozofia prawa XIX i XX wieku (Kraków, Wydawnictwo Uniwersytetu Jagiellońskiego 1999).

Sztompka P, Zaufanie. Fundament społeczeństwa (Kraków, Wydawnictwo Znak 2007)

Wronkowska S, 'Kryteria oceny prawa' in E Kustra (ed), Przemiany polskiego prawa (1989-1999), (Toruń, Wydawnictwo Uniwersytetu Mikołaja Kopernika 2001)

Wyrozumska A, 'Obiektywna czy subiektywna koncepcja umowy międzynarodowej?' in J Menkes (ed), Prawo międzynarodowe - problemy i wyzwania. Księga pamiątkowa Professor Renata Sonnenfeld - Tomporek (Warsaw 2006)

Wyrozumska A, Umowy międzynarodowe. Teoria i praktyka (Warsaw, Prawo i Praktyka Gospodarcza 2006)

Zajadło J, 'Bezpieczeństwo - celowość - sprawiedliwość: antynomie idei prawa' in J Jabłońska-Bonca, Guść J (eds), Problemy bezpieczeństwa prawnego perspektywy teorii i filozofii prawa (2002) IX Gdańskie Studia Prawnicze 